\title{
Study and Analysis on the Significance of Traditional Classic Culture in the Cultivation of Higher Vocational Students' Humanistic Literacy
}

\author{
Xiangdong $\mathrm{Fu}$ \\ Hunan Modern Logistics College \\ Changsha, China
}

\begin{abstract}
It is of great significance to infiltrate traditional classical culture into the process of cultivating students' humanistic literacy in higher vocational colleges. This paper first briefly analyses the problems existing in the process of cultivating students' humanistic literacy in higher vocational colleges, then expounds the significance of adding traditional classical culture into the teaching of humanistic literacy in higher vocational colleges, and finally puts forward some suggestions for adding traditional classical culture to the cultivation of students' humanistic literacy in higher vocational colleges.
\end{abstract}

Keywords-traditional classical culture; higher vocational colleges; humanistic literacy; suggestions

\section{INTRODUCTION}

With the rapid development of China's social economy, all kinds of new ideological waves spring up like mushrooms after a spring rain. Under the influence of this so-called new trend of thought, excellent classical traditional Chinese culture has been challenged unprecedentedly. China has a long history and a culture of long standing. In the long history, various excellent traditional cultures shine like various noticeable cultural treasures. Under the new situation, the integration of traditional classical culture into the cultivation of humanistic literacy of higher vocational students has become one of the focuses of attention of every industry.

\section{PROBLEMS EXISTING IN THE CULTIVATION OF} HUMANISTIC LITERACY OF HIGHER VOCATIONAL COLLEGE STUDENTS

With the rapid economic development of China, it is urgent to strengthen humanistic literacy education. However, throughout the process of cultivating students' humanistic literacy in higher vocational colleges, various problems emerge in endlessly, which are mainly manifested in the following aspects.

First, most higher vocational colleges do not pay attention to highlighting students' humanistic literacy in the process of students' training, only focus their attention on skills training. Many employers often complain that students' professional skills and skills are still able to deal with and cope with various problems in their work, but they generally lack professional ethics and social responsibility. In the teaching process lacking humanistic literacy education, the problem of "having technology but without morality" is very common. Graduates from higher vocational colleges cannot be real excellent professionals if they only have good skills but improper attitude and inactive thinking in the work. The reasons for this embarrassing situation are closely related to the lack of humanistic literacy education in higher vocational colleges. Because there is no corresponding traditional classical culture in humanistic literacy education, students' humanistic literacy is worrying as a whole, which will seriously affect their future career path.

Secondly, the content of classical traditional culture and humanistic literacy is very few in the curriculum of some higher vocational colleges. In China, the development and curriculum design are imbalanced in higher vocational colleges, and the effect is unsatisfactory. Many higher vocational colleges unilaterally think that they are carrying out vocational education. As long as they can improve students' vocational skills, they will be good schools. They pay little attention to the cultivation of humanistic literacy of students. Therefore, in the diversified curriculum design, there are many specialized courses and skills courses, but few courses are really related to humanistic literacy. Without the teaching and edification of corresponding courses, it is not surprising that vocational students have little knowledge of humanistic literacy.

Thirdly, there is a serious lack of investment in the activities of humanistic literacy and excellent traditional culture in higher vocational colleges. The so-called "skillful women can't cook without rice" is also true in the transmission of traditional classical culture and humanistic quality in higher vocational colleges. Almost all schools have invested a lot in professional laboratory facilities and equipment, but when it comes to humanistic literacy and traditional classical culture, they immediately "change their face". Under the "constraints" of hardware and software facilities, it is not surprising that higher vocational students lack humanistic literacy. Without the guarantee of hardware equipment, the humanistic quality teaching carried out by teachers is dry and not interesting at all. It is very difficult for students to learn, let alone improve the teaching quality and effect in an all-round way. 
Fourthly, most vocational college students lack traditional cultural knowledge. According to the survey, students in higher vocational colleges have a superficial understanding of traditional classical culture, let alone love traditional classical culture. Because of the conflict of their own attitudes, teachers appear to be very hard to please students in the process of carrying out education of traditional classical culture and humanistic literacy. Even if teachers spend more time and energy, and the students are unwilling to cooperate, the teacher's teaching is just a "beautiful looking" castle in the air. Over time, the lack of humanistic literacy and cultural literacy of students themselves is more unsatisfactory. Driven by the vicious circle, students are increasingly tired of education of humanistic literacy and traditional classical culture. In addition, most vocational college students lack traditional cultural consciousness and morality. In contemporary material-oriented society, students have long been lacking the influence and edification of traditional morality, and they have shortcomings in getting along with people and dealing with people and things. These are the basic contents and one of key teaching contents that should be guaranteed in the cultivation and teaching of humanistic literacy, and also paid attention by the teachers of related disciplines in higher vocational colleges in the future.

\section{ThE SIGNIFICANCE OF AdDING TRADITIONAL Classical Culture to THE TEACHING OF HuMANisTiC LITERACY IN HIGHER VOCATIONAL COLLEGES}

With the general absence of the traditional classical culture of vocational students, it is of great significance to strengthen the relevant content of humanistic education, which is mainly manifested in the following aspects. Firstly, it is very important to add traditional classical culture to the cultivation of humanistic literacy of higher vocational students for the transmission of socialist core values. Teachers in higher vocational colleges often find it hard to find good materials and carriers when they teach students about socialist core values. With the development of traditional classical culture, it is easy for teachers in the cultivation and penetration of core values. Among many traditional Chinese classical cultures, there are many contents related to the state, nationality and society. Teachers can combine these contents with the core values of socialism, dig deeply into the essence of Chinese traditional classical culture, so that students have a strong sense of identity with Chinese traditional culture, and traditional culture and core values interact and promote each other.

Secondly, it can improve students' moral accomplishment in an all-round way by incorporating traditional classical culture into the teaching of humanistic literacy in higher vocational colleges. So, students can gradually establish correct outlook on life and values. In today's complex society, the lack of humanistic literacy and feelings is very common, but with the traditional classical culture, everything will become different. A variety of rich and colorful educational resources and humanistic materials are contained in excellent traditional Chinese culture. In the process of continuous indepth study, higher vocational students gradually abandon the previous wrong ideas, choose positive ideas to influence themselves in future work and study, and set up the correct view of life, values and morals to lead their life.

Thirdly, it can help students improve their interpersonal relationships and their emotional integrity by adding traditional classical culture into the teaching of humanistic literacy in higher vocational colleges. In traditional classical Chinese culture, "benevolence and trustworthiness" thoughts and feelings abound. In the daily teaching of humanistic literacy, the relevant content should be included in. With the transmission of traditional classical culture, students' minds have become more open, and the quarreling has gradually disappeared in the process of getting along with others. Under the influence of traditional classical culture, the estrangement and contradiction between people have also been reduced, and students become more tolerant and generous. Politeness has become the key point for higher vocational students to get along with people. At the same time, under the influence of the traditional "benevolence" thought, vocational college students transform from indifference into caring for others and helping others, which is extremely beneficial to the healthy growth of vocational college students in the future.

\section{Suggestions FOR AdDING TRAditional Classical Culture to THE Cultivation OF STUDENTS' HuMANistiC QUALITY IN HigheR VOCATIONAL COLLEGES}

\section{A. Strengthening the Cultivation of Humanistic Literacy and the Importance of Traditional Classical Culture in Running Schools}

In order to further strengthen the teaching of humanistic literacy and the penetration and transmission of traditional classical culture in higher vocational colleges, each higher vocational college should start from the source and devote great efforts to the idea of running a school. In addition to training students' vocational skills, vocational ethics and professional training should not lag behind. They should start from the actual situation of their own school, find a correct position, and seek a breakthrough in the teaching of humanistic literacy. In the teaching of humanistic literacy, the corresponding traditional classical culture is constantly integrated, so as to promote and realize the comprehensive improvement of higher vocational students' ideological literacy, spiritual literacy, cognitive ability and cultural education. At the same time, each higher vocational college has many differences in the purpose and concept of running a school, but in the face of humanistic literacy teaching, its important position is always unshakable. Humanistic literacy teaching should be regarded as another important part of teaching, rather than just the embellishment or supplement of teaching. Without ideology and morality, even if a person has the highest technical and professional skills, he will make little contribution to society and human beings. Only by constantly strengthening the importance of humanistic literacy and incorporating the corresponding excellent traditional culture, can the teaching of higher vocational colleges become complete and meaningful. 
B. Constantly Strengthening the Quality Construction of the Teaching Team and Helping Teachers of Higher Vocational Colleges Competent for the Humanistic Literacy Education Work

In the process of cultivating students' humanistic literacy, higher vocational colleges add traditional classical culture, which requires teachers to have quite high comprehensive quality and professional quality. In the process of carrying out relevant work, every higher vocational college must first take enhancing the quality of teachers as the basic starting point. Only when the quality of teachers is in place, can the transmission of traditional classical culture really come into effect in the process of cultivating students' humanistic quality and bring into play its actual effect. In the specific process of improving teachers' quality, each higher vocational college has its own direction and focus. In the process of improving teachers' humanistic quality and traditional classical cultural reserves in an all-round way, it should be "grounded" and not be far-fetched and unrealistic in any sense. Schools can regularly or irregularly organize teachers to participate in training and recharging of various contents, which mainly focus on improving teachers' humanistic literacy and traditional classical cultural reserves. Especially in some higher vocational colleges of science and engineering, teachers are relatively poor in humanistic literacy and knowledge of traditional classical culture. After working, it is found that teachers of all disciplines should have corresponding knowledge to carry out teaching activities smoothly. The lack of original knowledge needs to be supplemented in the process of continuing their work. Only by putting the cultivation of teachers' quality on the important agenda for a long time and unremittingly, can the cultivation of humanistic literacy in higher vocational colleges achieve good results day by day.

\section{Adding the Content and Elements of Traditional Classical Culture to the Curriculum Construction}

It is a long and systematic process for higher vocational colleges to incorporate traditional classical culture into the cultivation of students' humanistic literacy. It is not a teaching task that can be accomplished by shouting a few slogans in two or three times. In view of this, every higher vocational college can devote great efforts to the curriculum design in the process of cultivating students' humanistic literacy and transferring traditional classical culture. Higher vocational colleges can incorporate traditional classical Chinese culture as an optional or compulsory course into the actual teaching plan. For example, the introduction of traditional Chinese culture, appreciation of ancient Chinese poetry, and guide reading of Chinese classics can be used as optional or compulsory courses. Through these abundant and diverse curriculum arrangements, it is possible to improve humanistic literacy, originally indifferent to students, and traditional cultural connotation gradually and unconsciously, and eventually students can grow into a high-quality professional who not only knows the corresponding professional knowledge, but also has rich humanistic literacy.

\section{Effective Integration of Traditional Culture Teaching with Various New Media}

In the process of cultivating students' humanistic literacy and transferring classical traditional culture, it is also very important for teachers of higher vocational colleges to use the platform of network and new media skillfully. Teachers of all disciplines can effectively use various network platforms to carry out the transmission of traditional classical culture in the course of teaching. The network of traditional Chinese studies and the forum of traditional Chinese studies can become one of "main positions" of traditional culture teaching. At the same time, through a variety of new media, such as WeChat, microblog and other ways to subtly nurture students with traditional culture, so that students unconsciously improve their humanistic literacy, teaching effectiveness from quantitative to qualitative leap.

\section{CONCLUSION}

Through the above analysis, it can be seen that each higher vocational college should carry out targeted teaching activities in accordance with its own actual situation, so that every higher vocational college student can improve their humanistic literacy and humanistic feelings in the process of continuously improving their professional literacy.

\section{REFERENCES}

[1] Ji Zhijie. Research on Humanistic Literacy Development of Higher Vocational College Students from the Perspective of Chinese Traditional Culture. Modern Vocational Education, 2018 (9): 66-67. (in Chinese)

[2] Liu Yunlian, He Wenting. Research on the Humanistic Literacy of Higher Vocational College Students from the Perspective of Chinese Traditional Culture. Journal of Guangdong Light Industry Vocational and Technical College, 2015 (1): 31-34. (in Chinese)

[3] Zhao Xianjuan, Xiong Zhuangzhi. Approaches to Cultivating Humanistic Quality of Higher Vocational Students. Journal of Hube Adult Education College, 2016, 22 (2): 81-85. (in Chinese)

[4] Ouyang Juan. Humanistic Quality Training of Higher Vocational Students Based on Chinese Excellent Traditional Culture. Higher Education Forum, 2014 (5): 32-34. (in Chinese)

[5] Shen Li. Traditional Culture and Humanistic Quality Education for Higher Vocational College Students. Journal of Chongqing University of Science and Technology (Social Science Edition), 2011 (2): 195-196. (in Chinese) 